\title{
Pengaruh Pembiayaan Mikro Syariah Terhadap Tingkat Perkembangan Usaha Mikro Kecil Menengah (UMKM)
}

\author{
Muhammad Andi Prayogi ${ }^{1}$, Lukman Hakim Siregar ${ }^{2}$ \\ ${ }^{1}$ Dosen Fakultas Ekonomi dan Bisnis Universitas Muhammadiyah Sumatera Utara \\ e-mail:muhammadandi@umsu.ac.id \\ ${ }^{2}$ Dosen Fakultas Ekonomi Universitas Dharmawangsa \\ e-mail:lukman.fe@dharmawangsa.ac.id
}

\begin{abstract}
ABSTRAK
Penelitian ini bertujuan untuk mengetahui bahwa pengaruh pembiayaan mikro syariah terhadap tingkat perkembangan usaha UKM Pada PT. Cabang BRI Syariah Medan. Penelitian ini untuk melihat bahwa terdapat pengaruh yang signifikan pembiayaan mikro syariah terhadap tingkat perkembangan usaha UKM karena nilai t hitung > t tabel yaitu sebesar $7.196>2.024$ dan $t$ hitung adalah zona penolakan $\mathrm{H} 0$ sehingga $\mathrm{HO}$ ditolak (Ha diterima). Nilai R-Square sebesar 0,577 atau 57,70\%, ini berarti bahwa variabel tingkat perkembangan usaha UMKM $(\mathrm{Y})$ dipengaruhi oleh variabel pembiayaan mikro syariah (X). Sisa $42,30 \%$ kontribusi variabel lainnya tidak termasuk dalam penelitian ini. Berdasarkan hasil uji $\mathrm{F}$, nilai $\mathrm{F}$ hitung $>\mathrm{F}$ tabel sebesar $51,775>3,24$ dengan hipotesis H0 ditolak dan Ha diterima dengan signifikansi $0,000<0,05$ maka dapat disimpulkan bahwa variabel pembiayaan mikro syariah berpengaruh signifikan terhadap pembangunan tingkat UMKM Bisnis di PT. Cabang BRI Syariah Medan.
\end{abstract}

Kata kunci: Pembiayaan Mikro Syariah, Tingkat Perkembangan Usaha UMKM 


\title{
The Influence of Sharia Micro Financing On The Development Rate of Micro Small and Medium Enterprises (UMKM)
}

\begin{abstract}
This research aims to see that the influence of micro financing sharia on the level of SMEs business development at PT. BRI Sharia Branch Medan. The research of this study to see that there is a significant effect of micro sharia financing on the Level of SMEs Business Development due to the value of $t$ arithmetic $>t$ table that is equal to $7.196>2.024$ and $t$ arithmetic is the rejection zone $H_{0}$ so $H_{0}$ rejected (Ha accepted). R-Square value of 0,577 or 57,70\%, this means that variable of Business Development Level of UMKM (Y) influenced by variable of micro financing of sharia $(X)$. The remaining $42.30 \%$ of the contribution of other variables are not belong in this research. based on the output of F test, $F$ value count $>F$ table is 51,775 > 3,24 with $\mathrm{HO}$ hypothesis rejected and Ha accepted with significance 0,000 $<0,05$ hence can be concluded that variable of Micro Financing of Syariah have significant influence to development level of UMKM business at PT. BRI Sharia Branch Medan.
\end{abstract}

\section{Key words: Micro Sharia Financing, Level of MSME Business Development}

\section{PENDAHULUAN}

Sedikitnya lapangan pekerjaan menjadikan setiap masyarakat mengembangkan segala potensi yang dimilikinya. Salah satu potensi yaitu mengembangkan keterampilan dalam berwirausaha. Pada mulanya memulai suatu yang belum sama sekali kita perbuat itu sangat sulit, jika tidak ada kemauan yang tinggi segala sesuatunya tidak mungkin dapat terealisasi.Niat saja tidak bisa menjadi tolak ukur untuk memulai usaha, tentunya modal menjadi faktor penting dalam memulai usaha.Setiapentrepreneur (usahawan) pada awal mendirikan suatu usaha pastiterkendala dengan modal yang minim. Kendala ini dapat teratasi dengan adanya lembaga keuangan perbankan yang menyediakan pinjaman modal bagi mereka yang membutuhkan pinjaman kredit atau pembiayaan. Fungsi utama dari perbankan yaitu "Sebagai lembaga intermediasi yaitu menarikuangatau menghimpun dana di masyarakat dalam bentuk tabungan, deposito, giro setelah itu menyalurkannya dalam bentuk pembiayaan." Fungsi tersebut tidak hanya dijalankan oleh perbankan konvensional, akan tetapi perbankan syariah juga menjalankannya selain menjalankan fungsi dari mengelola zakat, infak dan sedekah. 
Published Desember 2017

EKONOMIKAWAN : Jurnal Ilmu Ekonomi dan Studi Pembangunan

ISSN : 1693-7600 (Print), ISSN : 2598-0157 (Online), http://furnal.umsu.ac.id//index.php/ekawan

Eksistensi perkembangan dari perbankan syariah yang ada sangat pesat, setelah adanya Undang-Undang Nomor 10 Tahun 1998 tentang Perubahan terhadap UndangUndang Nomor 7 Tahun 1992 tentang Perbankan yang lebih mengakomodasi dan memberi peluang bagi perkembangan perbankan syariah. AdanyaUndang-Undang tersebut adalah tidak lainuntuk memperkuat aturan yang ada. Di lain pihak agar tata kelola perbankan syariah lebih baik maka dikeluarkan Undang-undang Nomor 21 tahun 2008 tentang Perbankan Syariah yang secara tegas mengakui eksistensi dari perbankan syariah dan membedakannya dengan sistem perbankan konvensional. Pasal 1 ayat 7 Undang-Undang Nomor 21 tahun 2008 menjelaskan mengenai Perbankan Syariah bahwa "Bank syariah yaitu bank yang dalam melakukan kegiatan usahanya berdasarkan atas prinsip syariah dan menurut jenisnya terdiri dari Bank Umum Syariah (BUS) dan Bank Pembiayaan Syariah (BPRS)." Dalam menjalankan kegiatan usahanya, PT.BRI Syariah dapat memberikan pinjaman danadengan skemabagi hasil (mudarabah), pembiayaan dengan sistem pemberiandana (modal) ke bank (musyarakah), prinsip jual beli barang untuk mendapatkan profit (murabahah), atau pembiayaan barang modal dengan sistem titip sewa murni tanpa ada pilihan (ijarah), atau dengan sistem pemindahan kepemilikan atas barang yang akan disewa dari pihak bank oleh pihak lain (ijarah wa iqtina), akad salam, akad istisna', sewa menyewa yang diakhiri dengan kepemilikan (ijarah al-muntahiya bi tamlik), dan lainnya yang tidak menyalahi prinsip syariah.

Untuk menjadikan produk perbankan syariah agar berbeda dan bervariasi dibanding produk perbankan konvensional, adanya inovasi-inovasi dari produk perbankan syariahakan menarik para nasabahnya.Dalam hal ini dapat memungkinkan produk pada bank syariah memberipeluang yang lebih luas dalam rangka memenuhi kebutuhan nasabah terhadap kebutuhan mereka. Khususdalam hal penyaluran dana pinjaman kepada masyarakat, maka skema dari pembiayaannyadapat diberikan sesuai dengan kebutuhannasabah tersebut. Meskipun demikian,produk dari perbankan syariah secara teoritis tetap mengacu padapembiayaan mu arabah dan musyarakah sebagai akad inti dalam sistem bagihasil (loss and profit sharing). Dalam sistem bagi hasil, penentuan margin atau keuntungan bagi hasil dibuat diawal akad dengan menjelaskan kemungkinan adanya kerugian dan keuntungan. Maka dalam suatu proyek yangdilakukan nasabah, apabila terdapat kerugian maka akan ditanggulangi bersama.Dilain pihak pada sistem bagi hasil ini, jumlah keuntungan akan mengalami peningkatan sesuaidengan adanya peningkatan dari jumlah pendapatan,dalam sistem konvensional,besarnya pembayaran bunga tidak mengalami peningkatan meskipun terlihat jumlah keuntunganberlipat.Dengan aturan iniadanya kesempatanbagi parapengusaha kecil, mikro dan menengahuntuk mengembangkan usahanya berdasarkan asas kemitraan sebagaimanayangtelah ditetapkan dalam perbankan syariah (Kara, 2013, hal. 271). 
Published Desember 2017

נ. EKONOMIKAWAN : Jurnal Ilmu Ekonomi dan Studi Pembangunan

ISSN : 1693-7600 (Print), ISSN : 2598-0157 (Online), http://furnal.umsu.ac.id//index.php/ekawan

Fungsi dan peran serta dari UMKM sangatlahtinggi, karena sektor ini merupakan sumber pendapatan bagi setiap orang dan mampu menyediakan lapangan pekerjaan bagi mereka yang memliki pendidikan dan keterampilan rendah serta mampu mengurangi kemiskinan (Agyapong, 2010).UMKM untuk saat ini sangat didorong untuk berkembang oleh pemerintah, karena kemajuan dari UMKM dapat meningkatkan pertumbuhan ekonomi negara. UMKM sarana untuk mengurangi pengangguran dan penciptaan lapangan kerja baru.Pembangunan ekonomi Indonesia yang terlihat dalam lima tahun belakangan ini menargetkan pada pengentasan kemiskinan dan menciptakan lapangan pekerjaan. Adanya pencapaian sebesar 51,26 juta pada periode tahun 2008 pada Unit Usaha dari UMKM, terlihat ada peningkatan dari 44,78 juta unit pada tahun 2004. Sementara itu angkatan kerja yang terlibat dalam sektor ini mencapai 90,90 juta orang tahun 2008 meningkat dari 80,45 juta orang pada tahun 2004. (Bappenas, Rencana Pembangunan Jangka Menengah Nasional 2015-2019).Upaya untuk meningkatkan UMKM pada perekonomian nasional diperlukan serangkaian pembinaan yang bersumber pada masalah keterbatasan teknologi, informasi dan permodalan (Altman, 1968). Kondisi dan fakta di atas sejalan dengan hasil penelitian Emirbagetal (2006), dalam Husen (2012) yang menyimpulkan bahwa keberhasilan UMKM ditentukan oleh kepribadian yang dilakukan oleh para pengusaha(Purnomo, 2013) dan memiliki dampak langsung terhadap pembangunan ekonomi suatu negara. UMKM menciptakan lapanganpekerjaandengan biaya yang lebih rendah dan merupakan pencetus dalam inovasi dan fleksibilitas yang tinggi terhadap strategi bisnis dan pertumbuhan usaha (Husen, 2012).

\section{LANDASAN TEORI}

\section{Pembiayaan Mikro Syariah}

Memberikan dan penyaluran danakembali ke masyarakat merupakan tugas pokok dari bank, yaitu "Pemberian fasilitas penyediaan dana untuk memenuhi kebutuhan pihakpihak yang merupakan defisit unit (Antonio, 2001, hal. 160).Menurut Pramayati, (2008, hal.10). Pemberian pembiayaan Usaha Mikro itu sendiri adalah pinjaman dalam bentuk kredityang disalurkan oleh pihak perbankan kepada pengusaha UMKM yangdapat dimungkinkan diberikan tetapi belumbankable. Maksudnya adalah usaha tersebut dapat dijadikan sebagai usaha yang berkelanjutan dan dapat memperbaiki taraf hidup di dalam masyarakat.

Menurut Alim (2009, hal.14) menyatakan bahwa "Usaha mikro merupakan suatu usaha individu atau keluarga atau yang beranggotakan individu yang belum memiliki izin usaha secara lengkap.'Pengertian lain dikemukakan Sumitro (2004, hal.168), UMKM adalah "Usaha yang dilakukan oleh suatu perusahaan dengan tenaga kerja yang digunakan tidak melebihi dari 50 orang."Menurut International Management Communications Corporation (IMCC), microfinance atau pembiayaan mikro sebagai seperangkat teknik dan metode perbankan non-tradisional untuk membuka akses terhadap sektor yang tidak pernah tersentuh oleh jasa keuangan formal (Hadinoto, 2007). 
Published Desember 2017

EKONOMIKAWAN : Jurnal Ilmu Ekonomi dan Studi Pembangunan

ISSN : 1693-7600 (Print), ISSN : 2598-0157 (Online), http://furnal.umsu.ac.ld/index.php/ekawan

Pembiayaan mikro adalah fasilitas pembiayaan yang diberikan untuk kelangsungan dari usaha mikro (Ikatan Bankir Indonesia, 2014). Adapun usaha mikro menurut Keputusan Menteri Keuangan Nomor 40/KMK.06/2003 tanggal 29 Januari 2003 yaitu :"(a) Usaha produktif milik keluarga atau perorangan, (b)Penjualan maksimal Rp. 100 juta pertahun, (c) Kredit yang diajukan maksimal Rp. 50 juta.”Menurut Undang-Undang RI Nomor 20 Tahun 2008 tentang usaha mikro, kecil, dan menengah bahwa Usaha Mikro yaitu "Usaha produktif milik orang perorangan dan/atau badan usaha perorangan yang memenuhi kriteria usaha mikro sebagaimana diatur dalam Undang-Undang ini.'Penggolongan Usaha Mikro yaitu sebagai berikut:"(1) Memiliki kekayaan bersih paling banyak Rp50.000.000,00 (lima puluh juta rupiah) tidak termasuk tanah dan bangunan tempat usaha; atau (2) Memiliki hasil penjualan tahunan paling banyak Rp300.000.000,00 (tiga ratus juta rupiah).

Badan Pusat Statistik (BPS) menyatakan bahwa yang dikatakan usaha mikro itu terdiri dari 5 orang, termasuk tenaga yang tidak dibayar dan menurut Bank Indonesia, definisi mikro (SK Dir BI No. 31/24/KEP/DIR tgl 5 mei 1998) yang dikelola atau dijalankanmasyarakat yang kurang mampu. Dimiliki keluarga yang bersumber dari dalam negeri dan memiliki teknologi yang sangat sederhana. Lapangan usaha mudah untuk exit dan entry. (Pramayati, 2008, hal.5). Pembiayaan salah satu metodemenyalurkan dana yang tinggi dari suatu lembaga keuangan bank (Karim, 2010) yang penuh dengan risiko kerugian yang cukup besar (Afkar, 2015), namun juga memiliki peluang yang besar dalam mendapatkan laba. Perbankan syariah telah berkembang sejak tahun 2010 sampai 2011 dan mengalami peningkatan pada sektor ekonomi (Kara, 2013).Pembiayaan yang disalurkan oleh setiap perbankan syariah di Indonesia terdiri dari pembiayaan investasi, konsumsiserta modal kerja (Afkar, 2014) yang pada prinsip syariahnyapengelolaan dengan sistem bagi hasil, maupun dengan sistem kemitraan (Afkar, 2015).

Perbankan syariah merupakan suatu lembaga keuangan yang bergerak pada sektor riil dengan sistem bagi hasil, jual beli, serta jasa (Afkar, 2015). Adapun penggunaan akad pembiayaan syariah yang banyak digunakan oleh perbankan syariah yaitu "mudharabah, murabahah, musyarakah, ijarah, qard dan Istishna' (Ridlwan, 2016)."Adapun peran utama dari perbankan syariah yaitu untuk memberikan keringananuntuk pengusaha yang bergerak pada sektor riil untuk meningkatkan perekonomian di Indonesia. Sejak terkena krisis yang terjadi pada tahun 2008 akibat subprime mortgage, terjadi penurunan pada usaha properti sejak tahun 2015. Pemerintah untuk saat ini telah menggiatkan usaha UMKM dengan memberikan berbagai macam jenispenggunaan modal usaha. Perbankan syariah mempunyai peran yang sangat besar sebagai mitra usaha yang dapat memberikan bantuan dalam pembiayaan dengan sistem syariah. Salah satu peran perbankan syariah yaitu sebagai pemilik modal (Sahibul Ma'al) dan sebagai mitra usaha. Dalam hal iniUMKM dapat memperoleh sistem pembiayaan pada perbankan syariah sesuai dengan apa yang dibutuhkan. 


\section{Tingkat Perkembangan Usaha UMKM}

Dalam Bab I pasal 1 UU No 20 Tahun 2008 tentang UMKM, yang dimaksud dengan UMKM yaitu:"(a) Usaha Mikro yaitu “ Usaha produktif milik orang perorangan dan/atau badan usaha perorangan yang memenuhi kriteria Usaha Mikro sebagaimana diatur dalam Undang-Undang ini,'(b) Usaha Kecil yaitu "Usaha ekonomi produktif yang berdiri sendiri, yang dikelola oleh perseorangan atau badan usaha yang bukan dari group perusahaan atau diluar dari cabang perusahaan yang ada,ataupun menjadi bagian baik secaralangsung maupun tidak langsung usaha menengah maupun usaha besar yang memenuhi kriteria dari Usaha Kecil Menengah yang telah diatur dalam Undang-Undang ini,"(c) Usaha Menengah yaitu "Usaha ekonomi produktif yang berdiri sendiri, yang dilakukan oleh perseorangan atau badan usaha yang bukan merupakan anak perusahaan atau kantor cabang yang dikuasai, dimiliki atau bagian baik secara langsung maupun tidak terhadap Usaha Kecil atau Usaha Besar dengan jumlah kekayaan bersih atau hasil penjualan tahunan sebagaimana telah diatur dalam Undang-Undang ini.Pasal 19 UU No. 20 Tahun 2008 tentang UMKM, peningkatan dalam bidang SDM yang terdapat dalam Pasal 16 ayat (1) huruf c diterapkan dengan cara yaitu : (1) memasyarakatkan dan memberdayakan kewirausahaan; (2) adanya peningkatkandari segiaturan dan tehnis; serta(3) pengembangan sistem pada lembaga diklat untuk membuat suatu pendidikan, pelatihan, penyuluhan, motivasi dan kreativitas bisnis, dan penciptaan entrepreneur baru. Dari keseluruhan faktor tersebut SDM merupakan hal penting dalam berkembangnya UMKM agar dapat menciptakan wirausaha yang mandiri dari masyarakat. Oleh karena itu masyarakat perlu diberdayakan untuk meningkatkan kualitas SDM sehingga dapat mempengaruhi kualitas produksi yang dihasilkan dalam rangka meningkatkan perekonomian masyarakat untuk kesejahteraan masyarakat.

Menurut Soeharto, (2010, hal.185) adapun usaha yang berkembang itudiklasifikasikanke dalam5 tahap, yaitu "konseptual, permulaan,stabilitas, pertumbuhan (growth stage), serta kedewasaan.' Perkembangan usaha dari segi conceptual,yaitu:”(a) Mengenal peluang potensial, dalam mengetahui peluang potensial yang terpenting harus diketahui yaitu masalah-masalah yang ada dipasar,kemudian dicari solusi masalah yang telah terdeteksi. Solusi tersebut menjadi ide yang dapat direalisasikan, (b) Analisa peluang, tindakan yang bisa dilakukan untuk merespon peluang bisnis adalah dengan melakukan analisa peluang tujuan pasar yang ingin diraih kepada calon pelanggan potensial. Analisa ini dibuat untuk mengetahui respon pelanggan terhadap produk, proses, dan pelayanannya, (c) Mengorganisasi sumber daya, yang perlu dilakukan ketika suatu usaha berdiri adalah memanejemen sumber daya manusia dan uang. Tahapan inilah yang sering disebut sebagai permulaan dari suatu usaha. Tahapan inimenjadi sangat berartidikarenakan merupakan kunci keberhasilan untuk tahap selanjutnya. Tahap ini merupakan tahapan awal yang dapat dilakukan atau sering disebut dengan pemanasan (warming up), (d)Perpindahan sumber daya, merupakan suatu langkah dimana perpindahan sumber daya dan menerima resiko yaitu suatu langkah dimana langkah terakhir sebelum ke tahap permulaan. 
Published Desember 2017

EKONOMIKAWAN : Jurnal Ilmu Ekonomi dan Studi Pembangunan

ISSN : 1693-7600 (Print), ISSN : 2598-0157 (Online), http://furnal.umsu.ac.ld/index.php/ekawan

Agar mencapai suatu tujuan yang ingin dicapai usaha dapat berkembang apabila dikelola dan diatur dengan baik, terproses dan terlihat adanya peningkatan dari waktu ke waktu. Menurut chandra (2000, hal. 121) menyatakan bahwa "Berkembangnya suatu usaha terlihat dengan adanya peningkatan omset penjualan."Pengembangan dapat diartikan sebagai bentuk dalam peningkatan kemampuan konseptual, teoritis, teknis, dan moral individu yang dikembangkan melalui pendidikan dan pelatihan. Pengembangan UKM lebih dituju kepada pelaku ekonomi yang berdaya saing melalui peningkatan wirausaha dan peningkatan produktivitas yang didukung dengan upaya peningkatan adaptasi terhadap kebutuhan pasar, pemanfaatan hasil inovasi dan penerapan teknologi. (Afifuddin, 2010, hal.180). Pengaruh dari pengembangan UMKM di Indonesia dan melihat peran serta pemerintah dalam meningkatkan pertumbuhan UMKM di Indonesia memiliki hasil positif, baik secara langsung maupun tidak langsung. (Tambunan, 2009, hal.4). Pengembangan UMKM pada hakikatnya me-rupakan tanggungjawab bersama antara pemerintah dan masyarakat. Dengan melihat kendala yang muncul yang sering dihadapi oleh UMKM, maka diperlukan adanya suatu upaya-upaya yaitu:" (1) Menciptakan suatu iklim usaha yang kondusif, (2) Bantuan Permodalan, (3) Perlindungan Usaha, (4) Pengembangan Kemitraan, (5) Pelatihan, (6) Mengembangkan Promosi, dan (7) Menjalin Kerjasama yang baik. (Hafsah, 2004, hal.43-44)."

\section{METODE PENELITIAN}

Penelitian yang dilakukan menggunakan jenis pendekatan asosiatif kuantitatif. Jumlah populasi dari penelitian ini yaitu nasabah PT. BRI Syariah Cabang Medan yang berjumlah 40 orang. Dalam penentuan sampel penulis mengambil sampling purposive yakni teknik pengambilan sampel dengan suatu pertimbangan tertentu, maka sampel yang di ambil adalah 40 orang pada PT. BRI Syariah Cabang Medan. Dalam mengumpulkan data, penulis menggunakan cara kuesioner, wawancara dan studi dokumentasi. Sedangkan teknik untuk menganalisa data yaitu menggunakan analisis Regresi Linier sederhana. Dalam penelitian ini, peneliti menggunakan bantuan program software SPSS 23.0 for windows. Untuk mengetahui pengaruh variabel bebas dan variabel terikat digunakan rumus analisis regresi sederhana yaitu:

$$
\mathrm{Y}=\mathrm{a}+\mathrm{bX}
$$

dimana :

$\mathrm{X}=$ Variabel Independen (Pembiayaan Mikro Syariah)

$\mathrm{Y}=$ Variabel dependen (Tingkat Perkembangan Usaha UMKM)

$\mathrm{a}=$ Konstanta

$\mathrm{b}=$ Koefisien regresi 


\section{HASIL DAN PEMBAHASAN}

1. Uji asumsi klasik

\section{a. Uji Normalitas}

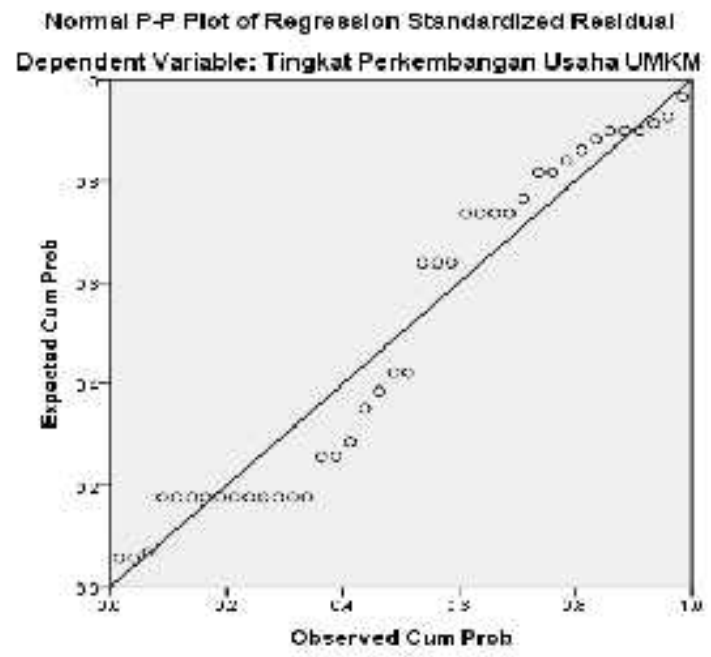

\section{Gambar 2}

Uji Normalitas

Adapun tujuan dari Uji Normalitas yaitu untuk menguji apakah hasil dalam pengolahan regresi, variabel dependen (Tingkat Perkembangan Usaha UMKM) dan independen (Pembiayaan Mikro Syariah)yang mana setiap variabel-variabelnya mempunyai distribusi normal atau tidak mendekati normal dapat dilakukan dengan uji PP plot standardized residual. Berdasarkan gambar di atas terlihatpenyebaran disekitar jalur garis diagonal. Oleh karena itu berdasarkan uji normalitas dapat dinyatakan bahwa data terdistribusi normal.

\section{b. Uji Heterokedastisitas}

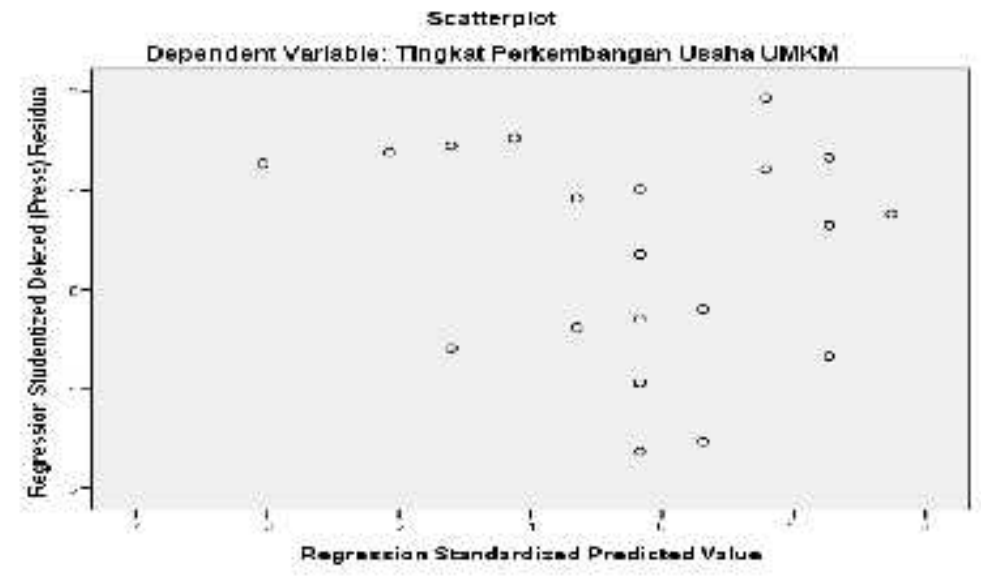

Gambar 2

Uji heterokedastisitas 
Gambar 2 menunjukkan adanya penyebaran titik-titik secara acak yang tidak berkumpul atau tidak membentuk pola yang jelas/teratur, tersebar baik terlihat di atas dan di bawah angka 0 terhadap sumbu Y, sehingga hasil menunjukkan tidak terjadinya heterokedastisitas pada model regresi ini.

\section{Uji Determinasi (R-Square)}

Tabel 1

Uji determinasi (R-Square)

Model Summary ${ }^{b}$

\begin{tabular}{|l|l|r|r|r|}
\hline Model & R & R Square & \multicolumn{1}{|c|}{$\begin{array}{c}\text { Adjusted R } \\
\text { Square }\end{array}$} & $\begin{array}{c}\text { Std. Error of } \\
\text { the Estimate }\end{array}$ \\
\hline 1 & $.759^{\mathrm{a}}$ & .577 & .566 & 1.55651 \\
\hline
\end{tabular}

a. Predictors: (Constant), Pembiayaan Mikro Syariah

b. Dependent Variable: Tingkat Perkembangan Usaha UMKM

Dari uji determinasi di atas menunjukkan bahwa nilai R-Square sebesar 0,577 atau 57,70\%, hal ini menunjukkan variabel Tingkat Perkembangan Usaha UMKM (Y) dipengaruhi oleh variabel Pembiayaan Mikro Syariah (X). Sisanya sebesar 42,30\% adanya kontribusi variabel lain yang tidak termasuk di dalam penelitian ini.

\section{Uji Hipotesis}

\section{Tabel 2}

Uji F

ANUVA

\begin{tabular}{|c|c|c|c|c|c|c|}
\hline & & $\begin{array}{l}\text { Sur of } \\
\text { SClal }=5\end{array}$ & df & Mean Square & $F$ & Sig: \\
\hline \multirow[t]{3}{*}{1} & Regression & 25.431 & . & \multirow{3}{*}{$\begin{array}{r}12 t .43 \\
2.423\end{array}$} & \multirow[t]{3}{*}{31115} & \multirow[t]{3}{*}{. $\mathrm{JJJ}^{2}$} \\
\hline & Residual & 92.063 & 38 & & & \\
\hline & Tu.el & $2 \cdot 7500$ & 39 & & & \\
\hline
\end{tabular}

a. DependentVariable: Tinqkat Perkembanqan Usaha JMKIM

b. Predictors: (Constant), Pembiayaar Milkr Syar ar

Terlihat dari pengolahan data di atas bahwa nilai $F_{\text {hitung }}>F_{\text {tabel, }}$ yaitu 51,775 $>3,24$. Hal ini dengan tingkat signifikan $0,000<0.05$, berarti $\mathrm{H}_{0}$ ditolak sedangkan $\mathrm{H}_{\mathrm{a}}$ diterima. Berarti Pembiayaan Mikro Syariah berpengaruh signifikan terhadap Tingkat Perkembangan Usaha UMKM. 


\section{Uji Regresi Sederhana}

\section{Tabel III. Uji t}

Coeficients $^{\text {a }}$

\begin{tabular}{|c|c|c|c|c|c|c|}
\hline \multirow[b]{2}{*}{ Mo:e } & & \multicolumn{2}{|c|}{ J-stanc ardiced Coeffixiznts } & $\begin{array}{l}\text { Slar da dized } \\
\text { Coeffic erts }\end{array}$ & \multirow[b]{2}{*}{1} & \multirow[b]{2}{*}{ Eig } \\
\hline & & $E$ & Std.E"or & Eeta & & \\
\hline \multirow[t]{2}{*}{1} & (Co $\operatorname{s:an}^{-2}$ & 475 & 3387 & & 4.35 & $66=$ \\
\hline & $\begin{array}{l}\text { Pembiayaan Miko } \\
\text { Syaria- }\end{array}$ & 855 & $\cdot 19$ & 759 & 7195 & $.00:$ \\
\hline
\end{tabular}

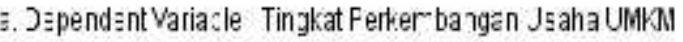

Tabel di atas terlihat bahwasanyanilai constanta sebesar 1,476, sedangkan nilai pembiayaan mikro syariah adalah 0,856 . Sehingga persamaan regresinya yaitu: $Y=$ $1,476+0,856$ X. Konstanta sebesar 1,476 menyatakan bahwa jika tidak ada Pembiayaan Mikro Syariah, maka nilai dari Tingkat Perkembangan Usaha UMKM sebesar 1,476. Koefisien regresi $\mathrm{X}$ sebesar 0,856 menyatakan bahwa setiap penambahan 1 nilai Pembiayaan Mikro Syariah, maka nilai Tingkat Perkembangan Usaha UMKM bertambah sebesar 0,856. Dari tabel di atas juga terlihat $t_{\text {hitung }}>t_{\text {tabel }}$, yaitu 7, $196>$ 2,024. Dari perhitungan tersebut maka $\mathrm{H}_{0}$ ditolak dan Ha diterima, terlihat ada pengaruh Pembiayaan Mikro Syariah terhadap Tingkat Perkembangan Usaha UMKM.

\section{KESIMPULAN}

Pembiayaan Mikro Syariah berpengaruh signifikan terhadap perkembangan UMKM padanasabah PT. BRI Syariah Cabang Medan. Hal ini dinyatakan dari hasil uji t adanya pengaruh Pembiayaan Mikro Syariah terhadap Tingkat Perkembangan Usaha UMKM pada nasabah PT.BRI Syariah Cabang Medan dengan nilai $t_{\text {hitung }}>t_{\text {tabel }}$ atau 7,196 $>2,024$ di mana nilaisignifikansinya $0,000<0,05$. Pembiayaan Mikro Syariahdiperoleh angkakoefisien determinasi $\mathrm{R}$-Square $=0,577$ atau 57,70\%. Hal ini terlihat bahwa variabelindependen Pembiayaan Mikro Syariahdalam menjelaskan variabel dependenTingkat Perkembangan Usaha UMKM pada nasabah PT.BRI Syariah Cabang Medansebesar 57,70\%, sisanya sebesar 42,30\% dijelaskan oleh variabel lain di luar model yang tidak diteliti.Berdasarkan hasil pengujian uji $\mathrm{F}$, nilai $\mathrm{F}_{\text {hitung }}>\mathrm{F}_{\text {tabel }}$ adalah 51,775 > 3,24dengan hipotesis $\mathrm{H}_{0}$ ditolak dan $\mathrm{H}_{\mathrm{a}}$ diterima dengan signifikansi 0,000 $<0,05$ maka dapat disimpulkan yaitu variabel Pembiayaan Mikro Syariah berpengaruh signifikan terhadap Tingkat Perkembangan Usaha UMKM Pada PT. BRI Syariah Cabang Medan.

\section{DAFTAR PUSTAKA}

Afkar, Taudlikhul. Pengaruh Pembiayaan Usaha Mikro, Kecil, Menengah (UMKM) dan Kecukupan Modal Terhadap Kemampuan Mendapatkan Laba Dari Aset Perbankan Syariah Di Indonesia. Al-Uqud: Journal of Islamic EconomicsVolume 1 Nomor 2, July 2017

Agyapong, Daniel. 2010. Micro, Small and Medium Enterprises' Activities, Income Level and Poverty Reduction in Ghana - A Synthesis of Related Literature. Journal of Business and Management. Vol.5, No.12, December 2010

Alma, Buchari, 2010, Kewirausahaan, Edisi Revisi, Bandung: Alfabeta. 
Published Desember 2017

EKONOMIKAWAN : Jurnal Ilmu Ekonomi dan Studi Pembangunan

ISSN : 1693-7600 (Print), ISSN : 2598-0157 (Online), http://furnal.umsu.ac.id//index.php/ekawan

Amir Machmud. Strategi Pemberdayaan Usaha Mikro Kecil Menengah Melalui Peran Lembaga Keuangan Syariah Dalam Upaya Pengentasan kemiskinan Di Indonesia.

Semnas Fekon: Optimisme Ekonomi Indonesia 2013, Antara Peluang dan Tantangan.

Amalia, Euis, 2009, Keadilan Distributif dalam Ekonomi Islam: Penguatan Peran LKM dan UKM di Indonesia, Jakarta: PT. Raja Grafindo Persada,

Antonio, Muhammad Syafi'i, 2001, Bank Syariah, dari Teori Ke Praktek, Jakarta: Gema Insani Press.

Bank Indonesia, 2010, Laporan Perkembangan Perbankan Syariah tahun 2009, Jakarta: Direktorat Perbankan Syariah: Bank Indonesia.

Bastian, Bustami. et al., eds., 2007, Mari Membangun Usaha Mandiri. Cet. II, Yogyakarta: Graha Ilmu.

Beik, Irfan Syauqi, 2007, Bank Syariah dan Pengembangan Sektor Riil. Jakarta: pesantrenvirtual.com.

Darawati, Ni Made Dwi dan I Wayan Wenagama. 2013. Efektivitas dan Dampak Program Dana Penguatan Modal Lembaga Usaha Ekonomi Pedesaan (DPM-LUEP) Terhadap Pendapatan dan Kesempatan Kerja Petani Padi di Kabupaten Tabanan. Jurnal EP. Vol.2, No.10, h: 449-456.

Data BPS tahun 2006.

Feni Dwi Anggraeni, Imam Hardjanto, Ainul Hayat. Pengembangan Usaha Mikro, Kecil, Dan Menengah (UMKM) Melalui Fasilitasi Pihak Eksternal Dan Potensi Internal (Studi Kasus pada Kelompok Usaha "Emping Jagung" di Kelurahan Pandanwangi Kecamatan Blimbing, Kota Malang). Jurnal Administrasi Publik (JAP), Vol. 1, No. 6, Hal. 1286-1295

Kara, Muslimin dan Jamaluddin, 2010, Pengantar Kewirausahaan, Makassar: Alauddin Press.

Karim, A. 2009, Fiqh Muamalat dan Perbankan Syariah. Seminar Syariah Islam. Jakarta: Muamalat Institute.

Nizarul, Alim, 2009, Pembiayaan Syari'ah Untuk Usaha Mikro dan Kecil: Studi Kasus Dan Solusi, Cet. I, Surabaya: PT. Bina Ilmu.

Peraturan Menteri Keuangan No. 135/PMK.05/2008 tentang Fasilitas Penjaminan Kredit Usaha Rakyat yang telah diubah dengan Peraturan Menteri Keuangan No. 10/PMK.05/2009.

Pramayati, Alika. 2008. Studi Kelayakan Bisnis Untuk UKM. Yogyakarta: Media Prindo.

Prawirokusumo, Soeharto, 2000, Kewirausahaan dan Manajemen Usaha Kecil, Cet. I, Yogyakarta: BPFE Yogyakarta.

Purnomo, Ratno dan Sri Lestari. 2010. Pengaruh Kepribadian, Self-Efficiacy dan Locus Of Control Terhadap Persepsi Kinerja Usaha Skala Kecil dan Menengah. Jurnal Ekonomi Pembangunan. Vol.1, No. 2, September 2010.

Tambunan, D. T, 2009, UMKM di Indonesia . Bogor : Ghalia Indonesia. 